Original Research Paper

\title{
Prevalence and Inhibition of Microbial Load on Chicken Eggs with Special References to Egg Quality and Hatchability
}

\author{
${ }^{1}$ Jehan Ismail Ibrahim, ${ }^{2}$ Dalia Mansour H. and ${ }^{1}$ Hosny Abdellatief Abdelrahman \\ ${ }^{I}$ Department of Food Hygiene and Control, \\ ${ }^{2}$ Department of Poultry and Rabbit Medicine, \\ Faculty of Veterinary Medicine, Suez Canal University, 41522, Ismailia, Egypt
}

Article history

Received: 07-7-2014

Revised: 28-8-2014

Accepted: 02-9- 2014

Corresponding Author:

Dalia Mansour, $\mathrm{H}$.

Department of Poultry and

Rabbit Medicine, Faculty of

Veterinary Medicine, Suez

Canal University, 41522 ,

Ismailia, Egypt

E-mail: Dalia97.mh@gmail.com

\begin{abstract}
A total of 304 random chicken egg samples obtained from layers of Balady and Battery systems. 144 of chicken Balady and Battery eggs (72 of each sample were divided into 18 batches) were used for bacteriological evaluation. Enterobactriacae (94.4, 33.3 and 27.7\%), Salmonella (77, 29 and 22\%), E.coli (44, 0 and 22\%) and Staphylococcus aureus (100, 97 and $98 \%$ ) were detected in shell, albumen and yolk in Balady eggs, respectively. Battery system showed lower incidence in Enterobactriacae (50, 16.6 and 22\%), Salmonella (41.6, 8 and $0 \%)$, E.coli $(27.7,9$ and 19\%) and Staphylococcus aureus (100, 83 and 95\%), respectively. Results concluded that the system in which the hens are housed contribute in rate of contamination of eggs. Staphylococcus aureus showed a higher prevalence rate compared to other pathogens in both laying systems. About 160 Balady eggs were selected for studying the effect of different pathogen inhibitors, 80 eggs for detecting preservation after 21 days at room temperature and the other 80 fertile Balady eggs for detecting hatchability and mortality. The efficacy of application of different pathogen inhibitors as Propionic acid at different concentration 10, 30, 50, 70 and 100\%, Hydrogen Peroxides $\left(\mathrm{H}_{2} \mathrm{O}_{2}\right) 3 \%$ and Virkon $\mathrm{S} 1 \%$ on eggs were recorded. Propionic acid $10 \%$, Virkon $\mathrm{S}$ and $\mathrm{H}_{2} \mathrm{O}_{2}$ showed nearly similar significant inhibitory effect on pathogens on egg shells ranged from 86 to $100 \%$, albumin from 33.4 to $100 \%$ and yolk from 34.3 to $100 \%$, while $30 \%$ Propionic acid has highly significant inhibitory effect on pathogen load ranged from 99.8 to $100 \%$. About $30 \%$ propionic acid concentration had a preservative effect on table eggs for 21 days at room temperature and increasing hatching percent up to $90 \%$ and lowering embryonic mortality to $10 \%$ in fertile eggs. The findings of this study indicate that $30 \%$ Propionic acid may be considered as a favorable disinfectant agent for the egg shell spraying.
\end{abstract}

Keywords: Egg Pathogen, Bacterial Inhibitors, Egg Quality and Hatchability

\section{Introduction}

Eggs can fully meet the requirements of all nutrients necessary for human development and life functions. At the same time, many nutrient substances present in egg create an excellent environment for the development of different microflora, including pathogenic microorganisms (Bufano-Nancy, 2000; Griffiths, 2005). Shell eggs without cracks have many natural barriers that prevent bacteria from entering and growing (Edema and Atayese, 2006). The ways of microbial contamination are vertical and horizontal transmissions Cox et al. (2000; Ellen et al., 2000; Smith et al., 2000). Pathogen penetration through the egg shell affect several aspects in keeping quality, hatching like early embryonic mortality, egg yolk infection and mortality before hatching (Berrang et al., 1999).

Salmonella can be regarded as two types of infections. The first is primarily of importance for public health by causing food borne illness. The other type causes severe disease leads to great economic losses in poultry industry (Anbessa and Shiferaw, 2013; CDC, 2014; SVA, 2014).

Egg shell contamination is the main reason for E. coli infection. Poor hatcher sanitation can leave a residue of 
$E$. coli from the previous hatch leads to yolk infections which occur during hatching process (Eric, 2011).

Staphylococcus aureus dominated on the shell and in yolk compared to egg white. The degree of contamination with these bacteria regarding to the source of eggs (Stępień-Pyśniak et al., 2009; Shareef et al., 2009).

Egg treatment with disinfectant is often used by the poultry industry to improve day-old chick quality, hatchability and keeping quality by reducing the microbial population on the egg shell surface Enev et al. (2005; Olayemi and Adetunji, 2013). Also, pathogen could penetrate egg during storage in storerooms, thus deteriorating their quality (Pavlov et al., 2006; Ivanov, 2008). For further safety, government regulations in some countries require special good hygienic practice and application of suitable detergent and sanitizer (Deeks, 2005; Baychev and Karadjov, 2006; Edema and Atayese, 2006; Best, 2007; Luc, 2007; Madec, 2007).

Therefore, the main objective of the present study was to:

- Detection and identification of some pathogenic bacteria present in eggs comparing different rearing systems

- Qualification and quantification the effect of different disinfectants on both edible and hatching eggs for studying their role in improving keeping quality and hatchability

\section{Material and Methods}

\section{Collection of Samples}

A total of 304 random egg samples, 144 of chicken Balady and Battery eggs (72 of each sample were divided into 18 batches each contain 4 eggs represented as one sample) were used for bacteriological evaluation. Every 4 eggs were placed in a plastic bag and transferred to the laboratory without delay for microbiological examination.

About 160 Balady eggs were selected for studying the effect of different pathogen inhibitors, 80 eggs for detecting preservation after 21 days at room temperature and the other 80 fertile Balady eggs for detecting hatchability and mortality.

\section{Preparation of Samples}

Egg samples were prepared for bacteriological examination according to (AOAC, 2000).

\section{Bacteriological Indices}

Were carried before and after application of pathogenic inhibitors (Table 1) in some selected pathogens as follows:

- $\quad$ Total Enterobactriacae counts (APHA, 1992)
- $\quad$ Isolation of E. coli (APHA, 1992)

- Isolation of Salmonella spp. (USDA/FSIS, 1998)

- Isolation of Staphylococcus aureus (Finegold and Martin, 1982)

Determination of $\mathrm{pH}$ : Using digital $\mathrm{pH}$ meter Model: cd 713 Qingdao TLead International Company Ltd.Shandong.China.

\section{Sensory Evaluation of Treated Egg According to Lawless and Hildegrade (2010)}

Odor, taste and texture of raw and cooked eggs before and after application of pathogenic inhibitors were tested.

The Efficacy of Application of Pathogenic Inhibitors upon the Hatchability Embryonic Mortality of Fertile Eggs

About 80 fertile eggs were treated with $\mathrm{H} 2 \mathrm{O} 2$, Virkon S and Propionic acid (10, 30, 50, 70 and 100\%), non-treated served as controls. Fertile eggs confirmed on 7 th day after incubation) only 80 fertile eggs (10/each) treatment were kept till hatching. Eggs were incubated in an automatic incubator with temperature $37.5 \pm 1^{\circ} \mathrm{C}$ and relative humidity $45-50 \%$ humidity for day $1-18$, then $65 \%$ for the last few days. Eggs were automatically turned in interval of two hours.

Hatchability: Was expressed as percentages of total fertile eggs.

\section{Effect of Disinfectants on Preservation of Table Eggs}

About 70 table eggs (10/each) were treated with $\mathrm{H} 2 \mathrm{O} 2$, Virkon $\mathrm{S}$ and Propionic acid (10, 30, 50, 70 and 100\%) eggs, 10 non-treated eggs served as controls. All eggs were examined after 21 days of incubation at room temperature for measuring rate of preservation (Menezes et al., 2012; SPSS 20, 1989-2014).

\section{Results}

Results were clarified in Fig. 1-3 and Table 2.

Higher incidence of pathogen detected in Balady over Battery system. Shell was the superior in contamination.

Preservation and both hatchability rate and embryonic mortality of treated fertile eggs and were improved after using Propionic acid 30\% followed by Propionic acid $10 \%, \mathrm{H}_{2} \mathrm{O}_{2}$ and Virkon-S.

Table 1. Concentration of pathogenic inhibitors

\begin{tabular}{llll}
\hline Product class & PH & Dilutions & \\
\hline Hydrogen Peroxide $\left(\mathrm{H}_{2} \mathrm{O}_{2}\right)$ & 7.5 & $3 \%$ & \\
Virkon S & 6.2 & $1 \%$ & \\
Propionic acid & 2.9 & $10 \%$ & (Prop.10\%) \\
Propionic acid & 2.8 & $30 \%$ & (Prop.30\%) \\
Propionic acid & 2.6 & $50 \%$ & (Prop.50\%) \\
Propionic acid & 2.4 & $70 \%$ & (Prop.70\%) \\
Propionic acid & 2.0 & $100 \%$ & (Prop. Conc). \\
\hline
\end{tabular}


Jehan Ismail Ibrahim et al. / American Journal of Animal and Veterinary Sciences 2014, 9 (4): 294.302 DOI: 10.3844/ajavssp.2014.294.302

Table 2. Quantitative and inhibitory percent of pathogenic inhibitors on bacterial load

\begin{tabular}{|c|c|c|c|c|}
\hline \multirow[b]{2}{*}{ Preparation } & \multicolumn{4}{|l|}{ Shell } \\
\hline & Entero.bact. & Salm. & E.coli & Staph \\
\hline Control & $43 \times 10^{2 \mathrm{a}} \pm 57.73$ & $1 \times 10^{2 \mathrm{a}}$ & $14 \times 10^{2 \mathrm{a}} \pm 56.73$ & $5 \times 10^{5 a} \pm 115.47$ \\
\hline Inhibition \% & 0 & 0 & 0 & 0 \\
\hline $\mathrm{H}_{2} \mathrm{O}_{2}$ & $2.3 \times 10^{2 \mathrm{~b}} \pm 0.57$ & $0^{\mathrm{b}}$ & $10^{\mathrm{c}} \pm 0.6$ & $7 \times 10^{4 b} \pm 11.54$ \\
\hline$\%$ of inhibition & 94.7 & 100 & 99.3 & 86 \\
\hline Virkon S & $2.2 \times 10^{2 \mathrm{~b}} \pm 0.57$ & $0^{\mathrm{b}}$ & $0^{c}$ & $3 \times 10^{4 c} \pm 57.73$ \\
\hline Inhibition $\%$ & 94.9 & 100 & 100 & 94 \\
\hline Prop. 10 & $2.5 \times 10^{2 b} \pm 0.57$ & $0^{\mathrm{b}}$ & $1.6 \times 10^{2 \mathrm{~b}} \pm 5.6$ & $6 \times 10^{3 \mathrm{~d}} \pm 1.15$ \\
\hline Inhibition\% & 94.2 & 100 & 89 & $99.8 \mathrm{~d}$ \\
\hline Prop. $30 \%$ & $0^{\mathrm{c}}$ & $0^{\mathrm{b}}$ & $0^{\mathrm{c}}$ & $8 \times 10^{2 \mathrm{~d}} \pm 1.15$ \\
\hline \multicolumn{5}{|l|}{ Albumen } \\
\hline Control & $2 \times 10^{2 \mathrm{a}} \pm 5.7$ & 0 & $1.2 \times 10^{2 \mathrm{a}} \pm 11.5$ & $4 \times 10^{2 a} \pm 2.88$ \\
\hline Inhibition\% & 0 & 0 & 0 & 0 \\
\hline $\mathrm{H}_{2} \mathrm{O}_{2}$ & $0^{\mathrm{b}}$ & 0 & $0.8 \times 10^{2 b} \pm 2.88$ & $1.2^{\mathrm{c}} \times 10 \pm 1.15$ \\
\hline$\%$ of inhibition & 100 & 0 & 33.4 & 97 \\
\hline Virkon S & $0^{\mathrm{b}}$ & 0 & $0^{\mathrm{c}}$ & $3.1 \times 10^{b} \pm 0.57$ \\
\hline Inhibition \% & 100 & 0 & 100 & 92.3 \\
\hline Prop. 10 & $0^{\mathrm{b}}$ & 0 & $0^{\mathrm{c}}$ & $1 \times 10^{c} \pm 2.30$ \\
\hline Inhibition \% & 100 & 0 & 100 & 97.5 \\
\hline Prop. $30 \%$ & $0^{\mathrm{b}}$ & 0 & $0^{\mathrm{c}}$ & $0^{\mathrm{d}}$ \\
\hline \multicolumn{5}{|l|}{ Yolk } \\
\hline Control & $2 \times 10^{2 \mathrm{a}} \pm 17.32$ & $6.4 \times 10^{2 \mathrm{a}} \pm 28.86$ & $3.8 \times 10^{\mathrm{a}} \pm 2.3$ & $4 \times 10^{2 a} \pm 8.66$ \\
\hline Inhibition\% & 0 & 0 & 0 & 0 \\
\hline $\mathrm{H}_{2} \mathrm{O}_{2}$ & $3 \times 10^{c} \pm 2.3$ & $0^{\mathrm{b}}$ & $2.5 \times 10^{\mathrm{b}} \pm 2.88$ & $5 \times 10^{\mathrm{b}} \pm 2.3$ \\
\hline$\%$ of inhibition & 85 & 100 & 34.3 & 87.5 \\
\hline Virkon S & $9 \times 10^{\mathrm{b}} \pm 11.54$ & $0^{\mathrm{b}}$ & $0^{\mathrm{c}}$ & $1.3 \times 10^{\mathrm{d}} \pm 1.73$ \\
\hline Inhibition\% & 100 & 100 & 100 & 96.8 \\
\hline Prop.10 & $1 \times 10^{\mathrm{cd}} \pm 2.3$ & $0^{\mathrm{b}}$ & $0^{\mathrm{c}}$ & $3 \times 10^{c} \pm 2.3$ \\
\hline Inhibition\% & 95 & 100 & 100 & 92.5 \\
\hline Prop. $30 \%$ & $0^{\mathrm{d}}$ & $0^{\mathrm{b}}$ & $0^{\mathrm{c}}$ & $0^{\mathrm{d}}$ \\
\hline
\end{tabular}

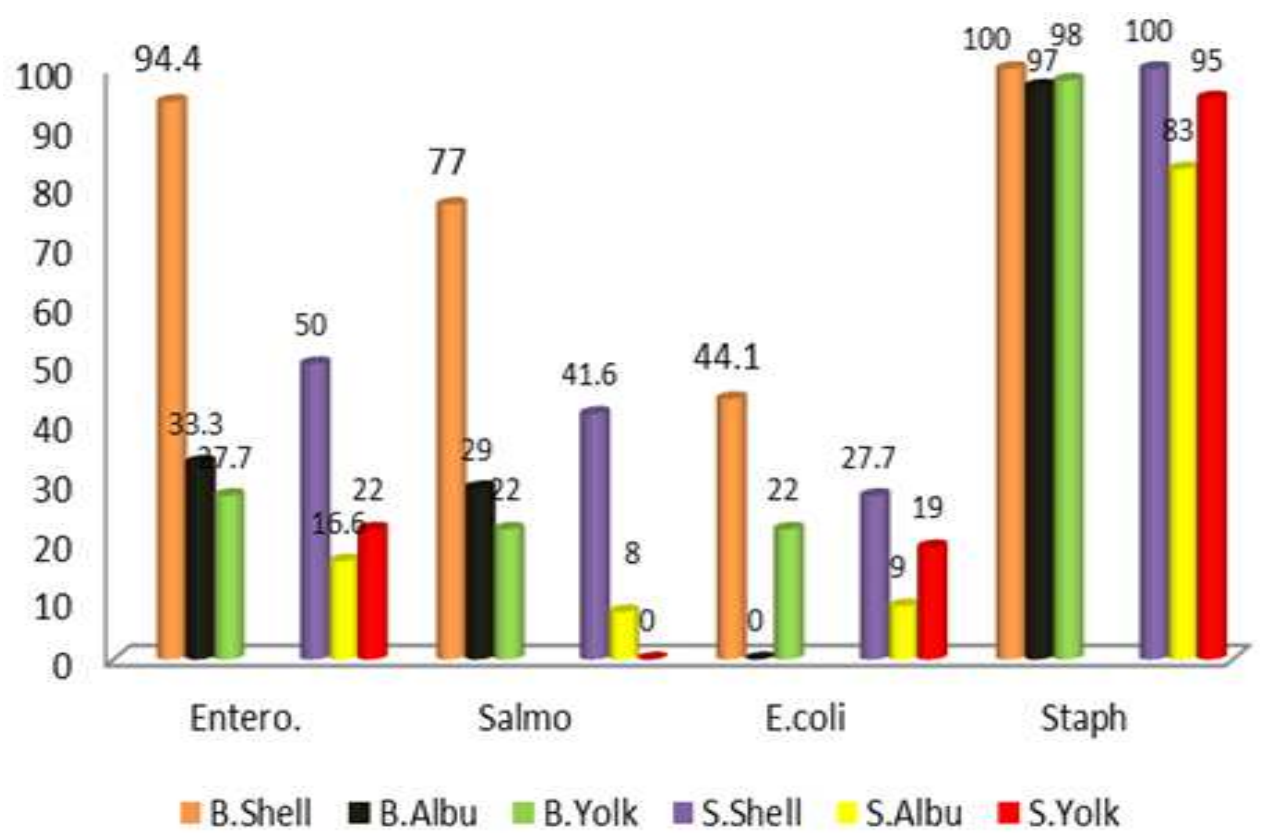

Fig. 1. Frequency distribution of pathogen in examined rearing systems *Balady (Shell-albumen-yolk) B.Shell-B.Albu-B. Yolk **Battary system(( Shell- albumen-yolk) S.Shell-S.Albu- S.Yolk 
Inhibition \% of pathogenic load on Balady eggs

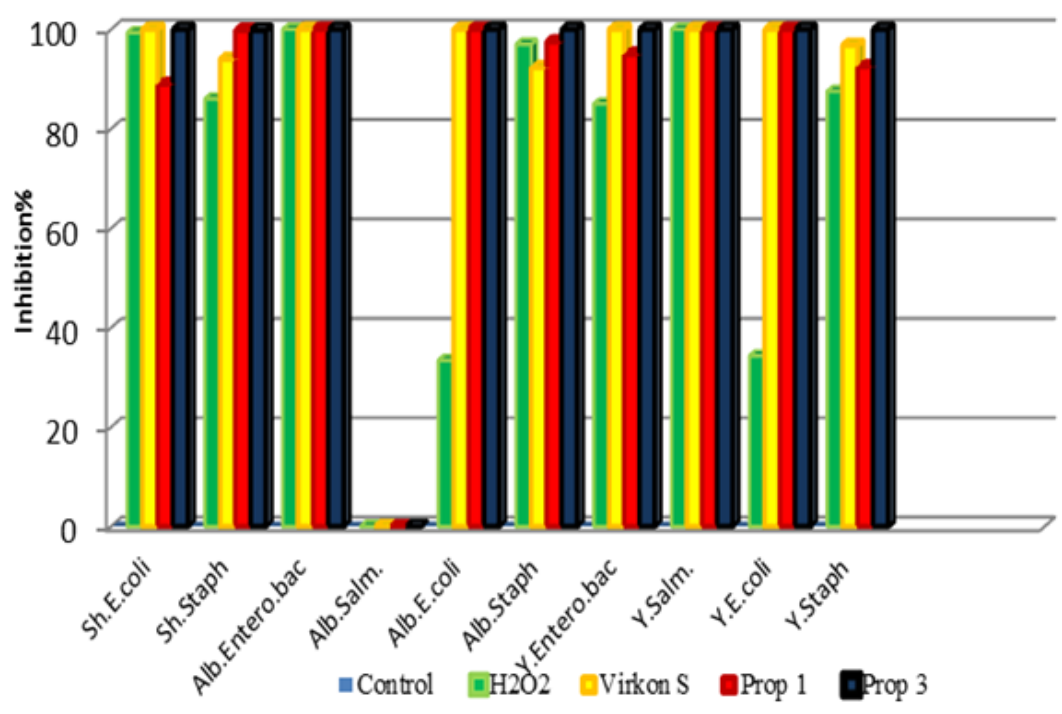

Fig. 2. Inhibitory percent of pathogenic inhibitors on bacterial load in Balady eggs

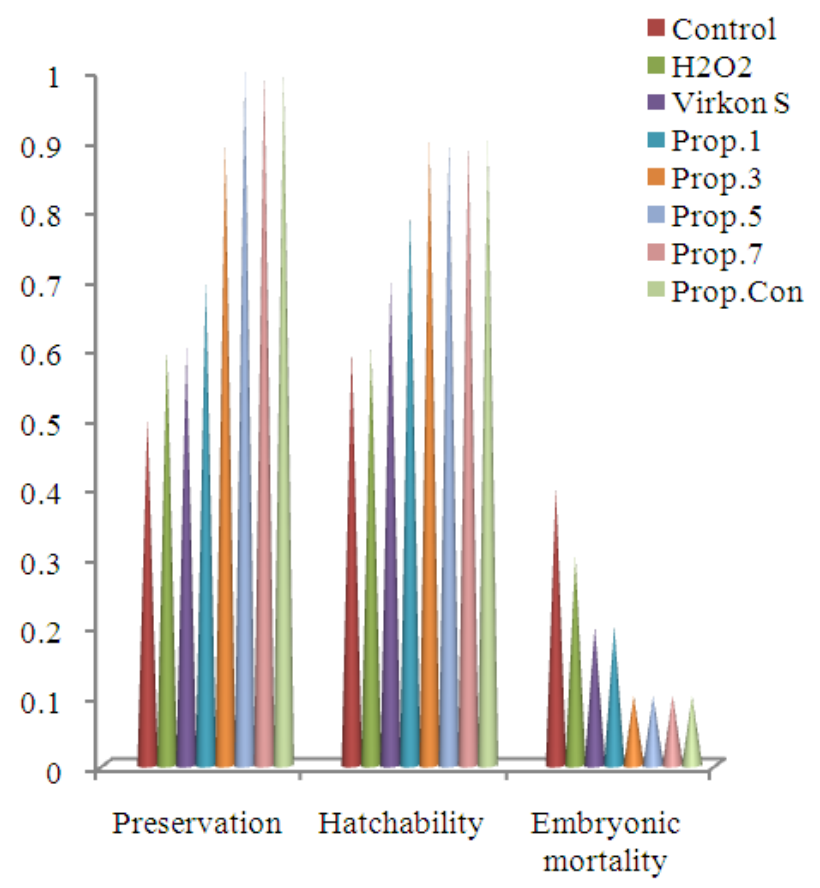

Fig. 3. Effect of different pathogenic inhibitors on table egg preservation, fertile egg hatching and embryonic mortality

Moreover, Propionic acid 50, 70 and 100\% showed similar results as $30 \%$ propionic acid.

\section{Discussion}

Egg and egg products are the primary vehicles for the transmission of pathogenic microorganism to man and it is estimated that about $50 \%$ of the foodborne cases from the consumption of contaminated egg or egg products (Suba et al., 2005; Sayed et al., 2009). Eggs have physical and biological defense mechanisms to protect the embryo against invasion and multiplication of microorganisms Jerzy and Dagmara (2009).

Influence of housing system on egg quality. The safety of eggs depends on the number of bacterial cells on shell and content of eggs for presence of factors that initiate pathogen multiplication (Ricke et al., 2001). The risk of illness resulting from consumption of contaminated eggs depends not only on the number of bacterial cells in eggs, but also on the type of bacteria (Bradshaw et al., 1990). Our data revealed a higher incidence of pathogen on shell of Balady over Battery system which may be attributed to poor sanitary conditions, initiating pathogen penetration through horizontal route and this result coincided with Smith et al. (2000); Knape et al. (2002); Theron et al. (2003). Our data indicated a highest incidence of pathogen on shell followed by albumen and finally yolk in both Balady and Battery system, these were attributed to the eggs temperature switch from $40^{\circ} \mathrm{C}$ to an ambient one during oviposition, creating a pressure gap through the egg shell to balance inside and outside pressure, the air will be "sucked" through the pores initiating entrance of most pathogen this was clarified by Turblin (2012). Moreover, our results proved lower incidence of pathogen in albumen than shell that might be due to the natural defense system of the egg in albumen which contains a number of proteins with demonstrated antimicrobial activities, such as lysozyme, bacterial cell lysis, metal binding and vitamin binding, prevent bacteria from entering and growing Edema and Atayese (2006). On contrary, Labaque et al. (2003); Jones et al. 
(2004) and Abdul Aziz et al. (2012) indicated that higher prevalence and counts of bacteria on egg shell was relative to the egg contents.

Frequency distribution of pathogen in laying egg systems. Results given in Fig. 1, shows that the frequency Enterobactriacae in Balady eggs were 94.4, 33.3 and $27.7 \%$ while in Battery eggs the percentages were 50, 16.6 and $22 \%$ in shell, albumen and yolk respectively. Enterobactriacae were recorded to play a role in spoilage and food poisoning Stępień-Pyśniak (2010). Our results showed high incidence of Enterobactriacae in Balady eggs in compared to Battery eggs these attributed to the poor sanitary conditions, similar results were recorded by Carter and Cole Jr. (1990).

The incidence of Salmonella spp. as shows in Fig. 1 in both Balady and Battery eggs were 77, 29 and 22\%; 41.6, 8 and $0 \%$ in shell, albumen and yolk respectively. Salmonella is of importance for public health by causing food borne illness in human beings and severe disease with economic importance in poultry industry (CDC, 2014; SVA, 2014). Lower incidence was recorded on the egg shells about (3.2\%) by Jones et al. (2004), Rodenburg et al. (2006) and De Reu et al. (2007). Other researcher detected lowest incidence of Salmonella in table eggs with $0.07 \%$ in egg content and $0.4 \%$ in shell by Poppe et al. (1998), De Reu et al. (2006) who found $0.18 \%$ and Begum et al. (2010) who reported variable and very low incidence of Salmonella. On contrary, Favier et al. (2000); Anon (2004) and Abdul Aziz et al. (2012) failed to isolate Salmonella spp. these results variation could be attributed to different control measures applied against these bacteria.

In the present study, the data obtained showed that $E$. coli was isolated from shell and yolk of Balady eggs but not from albumen (44, 0 and 22\%), while lower incidence detected in Battery system which were 27.5, 9 and 19\% of shell, albumin and yolk, respectively. Nearly similar results were obtained by Adesiyun et al. (2005) who found this bacterium on $58.7 \%$ of shell and in $4.3 \%$ of egg contents of farm eggs also, they added that the frequency of $E$. coli founded in eggs depending on their rearing sources.

The incidence of Staphylococcus aureus as shown in Fig. 1 was 100, 97 and $98 \%$ in Balady egg samples while in Battery system was 100, 83 and $95 \%$ in shell, albumin and yolk, respectively. Staphylococcus aureus has been reported by Hazariwala et al. (2002) as an important cause of diseases in poultry. McCullagh et al. (1998) found Staphylococcus aureus as a common isolate from the clinically diseased broilers and as a cause of yolk sac infection in broilers also they found both $E$. coli and Staphylococcus aureus may cause chick mortality after hatching. Moreover, Stępień-Pyśniak et al. (2009) demonstrated that Staphylococcus spp. dominated in the yolks $38.8 \%$, on the shells 58.9 and $2.5 \%$ in white of table eggs.

Variance in prevalence of bacterial contamination from shell and content might attributed to penetration rate. These results supported by Al-Ali et al. (2012) who found that Salmonella spp. were the highest in penetration rate followed by Stapylococcus aureus and Escherichia coli through egg pours.

Pathogenic inhibitors on eggs disinfectant preparations and concentrations need to be carefully scrutinized (Miguel et al., 2001). Hydrogen peroxide 3\% concentrations are commonly used in the poultry industry. Figure 2 Illustrated that $\mathrm{H}_{2} \mathrm{O}_{2}$ showed significant reduction on quantitative pathogenic load on shell ranged from 86 to $100 \%$, albumen from 33.4-to $100 \%$ and yolk from 34.3 to $100 \%$. It was clarified that $\mathrm{H}_{2} \mathrm{O}_{2}$ was more effective in reduction on shell than albumen and yolk respectively. This may be attributed to the inability of $\mathrm{H}_{2} \mathrm{O}_{2}$ to invade egg through pores. Nearly similar finding were recorded by Sander and Wilson (1999) who demonstrated that $3 \% \mathrm{H}_{2} \mathrm{O}_{2}$ was effective in reducing bacteria and Wells et al. (2011) who detected 3 $\log$ reductions in total bacterial count. Miguel et al. (2001) and Rodgers et al. (2001) recommended the use of $\mathrm{H}_{2} \mathrm{O}_{2}$ in poultry industry. Cox et al. (2000) found that Hydrogen peroxide is an effective chemical for the disinfection of fertile hatching eggs and does not adversely affect hatchability and also improve the hatching potential. Sheldon and Brake (1991), Padron (1995) Luc (2002) and Higgins et al. (2005) added that $\mathrm{H}_{2} \mathrm{O}_{2}$ showing no detrimental effects on both preservation and hatchability.

Virkon-S (1\%) has a wide spectrum bactericidal, veridical, fungicidal and good safety characteristic AI (2004). Figure 2 showed that Virkon-S had a significant reduction on pathogenic load on shell ranged from 94 to $100 \%$, albumen from 92.3 to $100 \%$ and yolk from 96.8 to $100 \%$. However, Gasparini et al. (1995) found that Virkon-S is effective but the prolonged use may leads to resistant pathogens. This finding coincides with those of Sidhu et al. (2002; Moustafa Gehan et al., 2004; Ellen, 2006).

Propionic acid is a bactericide and fungicide, safely used in poultry farms Haque et al. (2009). Figure 2 showed that Propionic acid $10 \%$ had a significant reduction on pathogenic load on shell ranged from 89 to $100 \%$, albumen from 97.5 to $100 \%$ and yolk from 92.5 to $100 \%$.

Our results proved that $30 \%$ propionic acid showed the highest reduction percent ranged from 99.8 to $100 \%$ 
on shell and content indicating high penetration availability. Similar inhibitory effect were recorded by using 50,70 and $100 \%$ concentration on shell, albumen and yolk, therefore $30 \%$ Propionic acid concentration was the lowest concentration having the highest significant inhibitory effect.

Figure 3 illustrated that spraying 30, 50, 70,100\% of propionic acid showed the highest preservation effect which attributed to its inhibitory effect on bacterial load of table eggs. Propionic acid 30\% was the lowest concentration having the highest preservation effect than $\mathrm{H}_{2} \mathrm{O}_{2}$ and Virkon-S. Similar data were recorded in both hatchability rate and embryonic mortality of treated fertile eggs; nearly similar data were detected by Higgins et al. (2005). Sensory evaluation of raw and cooked eggs not affected by spraying different pathogenic inhibitors. Our data indicated that $\mathrm{pH}(2.8-2.6-2.4-$ and 2) 30,50 , 70 and $100 \%$ of propionic acid, respectively, exhibits higher bactericidal activity this may be attributed to the Short chain of propionic acid which have been found to be efficacious in lowering the $\mathrm{pH}$ and thus don't allow the pathogenic microorganisms to grow, similar results were detected by Luckstadt, (2005). Superiority of propionic acid over other preparations in its bactericidal activity could be explained in the light of time of dissociation, whereas propionic acid dissociate slowly, so the antimicrobial effect depends upon the dissociation constant $(\mathrm{pKa})$ or $\mathrm{pH}$., at which $50 \%$ of the total acid is undissociated. The undissociated part of the molecule is related to the antimicrobial effect through penetration into the microbial cells (Davidson and Taylor, 2007).

\section{Conclusion}

From the above mentioned results it could be conclude that table eggs from Balady system were highly contaminated with various pathogenic microorganisms which render them unsafe for consumption than the battery system. Controlling most of eggs pathogen by using propionic acid $30 \%$ concentration was recommended, which is easily applicable, safe and improve both keeping quality and hatchability of table and fertile eggs Moreover urgent need for a strategy and protocol for applying strict hygienic measures at level of farm production until table use to control pathogen from pass from one generation to the next through fertile eggs.

\section{Author's Contributions}

All authors equally contributed in this work.

\section{Ethics}

The authors declare no conflict of interests with respect to the research, authorship and/or publication of this paper and has no direct financial relation with the commercial identities mentioned in this study.

\section{Reference}

Abdul Aziz, S., A.H. Sabry and A.E. Bahig, 2012. Microbial quality and content aflatoxins of commercially available eggs in Taif, Saudi Arabia. African J. Microbiol. Res., 6: 3337-3342.

Adesiyun, A., N. Offiah, N. Seepersadsingh, S. Rodrigo, V. Lash-ley and L. Musai, 2005. Microbial health risk posed by table eggs in Trinidad. Epidemiol Infect., 133: 1049-1056.

DOI: $10.1017 / \mathrm{S} 0950268805004565$

AI, 2004. W17-antec international. United Kingdom.

Al-Ali, M.A., S.N. Al-Bahry, I.Y. Mahmoud and S.K. Al-Musharafi, 2012. Penetration of food spoilage and food poisoning bacteria into fresh chicken egg: A public health concern. G.J.B.B., 1: 33-39.

Anbessa, D. and D. Shiferaw, 2013. Correlation of traditional knowledge with laboratory bases salmonella detection on egg shell and content of market sold egg. Asian J. Biological Sci., 6: 168-174.

Anon, 2004. Report of the survey of Salmonella contamination of UK produced shell eggs on retail sale. Food Standard Agency, London.

AOAC, 2000. Official methods of analysis. Association of Official Analytical Chemists, Gaithersburg.

APHA, 1992. Standard Method for Examination of Dairy Products. 14th Edn., American Public Health Association, Washington, D.C.

Baychev, J. and S. Karadjov, 2006. Bird flu. Anta-Neo, Sofia.

Begum, K., T.A. Reza, M. Hague, A. Hossain and F.M.K. Hassan et al., 2010. Isolation, Identification and antibiotic resistance pattern of Salmonella spp. from chicken eggs, intestines and environmental samples. Bangladesh Pharmaceut. J., 13: 23-27.

Berrang, M.E, N.A.Cox, J.F Frank and R. J. Buhr. 1999. Bacterial penetration of the eggshell and shell membranes of the chicken hatching egg. J. Applied Poultry Res., 8: 499-504. DOI: 10.1093/japr/8.4.499

Best, P., 2007. Risk assessors probe transport hygiene. Pig Int., 37: 6-7.

Bradshaw, J.G., D.B. Shah, E. Forney and J.M. Madden, 1990. Growth of Salmonella enteritidis in yolk of shell eggs from normal and seropositive hens. J. Food Prot., 53: 1033-1036. 
Bufano-Nancy, S., 2000. Keeping eggs safe from farm to table. Food Technol., 54: 192.

Carter, G.R. and R.J. Cole Jr., 2012. Diagnostic Procedures in Veterinary Bacteriology and Mycology. 5th Edn., Academic Press, San Diego, California, ISBN-10: 0323138187, pp: 620.

CDC, 2014. Salmonella in eggs: An unwelcome summer visitor.

Cox, N.A., M.E. Berrang and J.A. Cason, 2000. Salmonella penetration of egg shells and proliferation in broiler hatching eggs. A review. Poult. Sci., 79: 1571-1574. DOI: $10.1093 / \mathrm{ps} / 79.11 .1571$

Davidson, P.M. and T.M Taylor, 2007. Chemical Preservatives and Natural Antimicrobial Compounds. In: Food Microbiology: Fundamentals and Frontiers, Doyle, M.P. and L.R. Beuchat, (Eds.), ASM Press, Washington, D.C., pp: 713-734.

De Reu, K., B. Rodenburg, K. Grijspeerdt, M. Heyndrickx and F. Tuyttens et al., 2007. Bacteriological contamination of eggs and eggshell quality in furnished cages and non-cage systems for laying hens: An international on-farm comparison. Proceedings of the 18 European Symposiums on the Quality of Poultry Meat and 12 European Symposium on the Quality of Eggs and Egg Products, Prague, Czech Republic, pp: 46-47.

De Reu, K., M. Heyndrickx, K. Grijspeerdt, B. Rodenburg and F. Tuyttens et al., 2006. Assessment of the vertical and horizontal aerobic bacterial infection of shell eggs. J. World's Poutry Sci., 62: 564.

Deeks, A., 2005. Biosecurity doesn't cost-It pays. Poultry Int., 44: 14-16.

Edema, M.O. and A.O. Atayese, 2006. Bacteriological quality of cracked egg sold for consumption in Abeokuta, Nigeria. Int. J. Poultry Sci., 5: 772-775.

Ellen, G., 2006. Biosecurity procedures for poultry farm.

Ellen, H.H., R.W. Bottcher, E. Von Wachebfelt and H. Takai, 2000. Dust levels and control methods in poultry houses. J. Agri. Safety Health, 6: 275-282. DOI: $10.13031 / 2013.1910$

Enev, I., K. Kostov, D. Ivanova and P. Badarova, 2005. Aspergillosis in birds: Infectious diseases of animals. Matcom, Sofia.

Eric, G., 2011. E. coli infections in poultry. Nutrition on line. Diamond V, pp: 1-4.

Favier, G.I., M.E. Escudero, L. Velazquez and A.M.S. De Guzman, 2000. Reduction of Yersinia enterocoliticaand mesophilic aerobic bacteria in egg-shell by washing with surfactants and their effect on the shell microstructure. J. Food Microbiol., 17: 73-81.

DOI: $10.1006 /$ fmic. 1999.0295
Finegold, S.M. and W.J. Martin, 1982. Bailley and Scott Diagnostic Microbiology. 6th Edn., C.V. Mosby Co.St. Louis, Toronto, London.

Gasparini, R., T. Pozzi, R. Magnelli, D. Fatighenti and E. Giotti et al., 1995. Evaluation of in vitro efficacy of the disinfectant virkon. Eur. J. Epidemiology, 11: 193-197. DOI: 10.1007/BF01719487

Griffiths, M.W., 2005. Issues related to the safety of eggs and egg products: International seminar of pathology and poultry production. J. Food Properties, 13: 778-788.

Haque, M.N., R. Chowdhury, K.M.S. Islam and M.A. Akbar, 2009. Propionic acid is an alternative to antibiotics in poultry diet. Bang. J. Anim. Sci., 38: 115-122. DOI: 10.3329/bjas.v38i1-2.9920

Hazariwala, A., Q. Sanders, C.R. Hudson, C. Hofacre and S.G. Thayer et al., 2002. Distribution of staphylococcal enterotoxin genes among Staphylococcus aureus isolates from poultry and humans with invasive staphylococcal disease. Avian Dis., 46: 132-136. DOI: 10.1637/00052086(2002)046[0132:DOSEGA]2.0.CO;2

Higgins, S.E., A.D. Wolfenden, L.R. Bielke, C.M. Pixely and A. Torres-Rodriguez et al., 2005. Application of ionized reactive oxygen species for disinfection of carcasses, table eggs and fertile eggs. J. Applied Poultry Res., 14: 716-720.

Ivanov, I., 2008. Disinfection of eggs contaminated with some fungal moulds. Trakia J. Sci., 6: 98-101.

Jerzy, R. and S.P. Dagmara, 2009. Antimicrobial defence mechanisms of chicken eggs and possibilities for their use in protecting human and animal health. DOI: 10.2478/v10082-009-0004-7

Jones, D.R., M.T. Musgrove and J.K. Northcutt, 2004. Variations in external and internal microbial populations in shell eggs during extended storage. J. Food Protect, 67: 2657-2660. PMID: 15633667

Knape, K.D., C. Chavez, R.P. Burgess, C.D. Coufal and J.B. Carey, 2002. Comparison of eggshell surface microbial populations for in-line and off-line commercial egg processing facilities. Poult. Sci., 81: 695-698. DOI: $10.1093 / \mathrm{ps} / 81.5 .695$

Labaque, M.C., J.L. Navarro and M.B. Martella, 2003. Microbial contamination of artificially incubated Greater Rhea (Rhea Americana) eggs. Br. Poult. Sci., 44: 355-358. PMID: 12964617

Lawless, H.T. and H. Hildegrade, 2010. Sensory Evaluation of Food: Principles and Practice. 1st Edn., Springer Publisher, ISBN-10: 1441964886, pp: 619.

Luc, L., 2002. Clean water lines. Poultry Int., 41: 34-36. 
Luc, W., 2007. Good sanitation needs a detergent. Pig Int., 37: 12-13.

Luckstadt, C., 2005. Synergistic acidifiers to fight Salmonella. Feed Mix, 13: 28-30.

Madec, F., 2007. Keep out those pathogens. Pig Int., 37: 8-9.

McCullagh, J.J., P.T. McNamee, J.A. Smyth and H.J. Ball, 1998. The use of pulsed field gel electrophoresis to investigate the epidemiology of Staphylococcus aureus infection in commercial broiler flocks. Vet. Microbiol., 63: 275-281. DOI: 10.1016/S0378-1135(98)00240-5

Menezes, P.C., R.L. Evilda, P.M. Juliana, N.O. Wanessa and E.N. Joaquim Evêncio-Neto, 2012. Egg quality of laying hens in different conditions of storage, ages and housing densities. R. Bras. Zootec., 41: 2064-2069.

Miguel, R., J. El-Attrache and Pedrovillegas, 2001. Efficacy comparisons of disinfectants used by the commercial poultry industry. Av. Dis., 45: 972-977. DOI: $10.2307 / 1592876$

Moustafa Gehan, Z., W. Anwer and S.T. Moubarak, 2004. Evaluation of some chemical disinfectants used in commercial poultry hatcheries. J. Egypt. Vet. Med. Assoc., 64: 221-233.

Olayemi, F. and C. Adetunji, 2013. Effect of rinses on microbial quality of commercially available eggs and its components before processing from Ilorin in western Nigeria. Bitlis Eren Univ. J. Sci. Technol., 3: 44-47.

Padron, M., 1995. Egg dipping in hydrogen peroxide solution to eliminate Salmonella typhimurium from eggshell membranes. J. Avian Dis., 39: 627-30. DOI: $10.2307 / 1591818$

Pavlov, A., I. Vushin and H. Daskalov, 2006. Hygiene, technology and veterinary-sanitary control of meat, fish and eggs. Kota, Stara Zagora.

Poppe, C., C.L. Duncan and A. Mazzocco, 1998. Salmonella contamination of hatching and table eggs: A comparison. Can. J. Vet. Res., 62: 19-198.

Ricke, S.C., S.G. Birkhold and R.K. Gast, 2001. Eggs and Egg Products. In: Compendium of Methods for the Microbiological Examination of Foods, Downes, F.P. and K. Ito (Eds.), Washington, DC: Am Public Health Assoc, pp: 473-479.

Rodenburg, B., F. Tuyttens, K. De Reu, L. Herman and J. Zoons et al., 2006. Welfare of laying hens in furnished cages and in non-cage systems. Proceedings of the 40th International Congress of the ISAE Conference. Bristol, United Kingdom.
Rodgers, J.D., J.J. McCullagh, P.T. McNamee, J.A. Smyth and H.J. Ball, 2001. An investigation into the efficacy of hatchery disinfectants against strains of Staphylococcus aureus associated with the poultry industry. Vet. Microbiol., 20: 82: 131140. DOI: 10.1016/S0378-1135(01)00378-9

Sander, J.E. and J.L. Wilson, 1999. Effect of HO2 2 disinfection during incubation of chicken egg on microbial levels and productivity. J. Av. Dis., 43: 227-233. DOI: 10.2307/1592612

Sayed, M., M. Abdel-Azeem, M. Farghaly and R. Hassanein, 2009. Using of PCR assay for identification of Listeria monocytogenes recovered from table eggs. Vet. World, 2: 453-455.

Shareef, A.M., R.S. Mansour and K.K. Ibrahim, 2009. Staphylococcus aureus in commercial breeder layer flocks. Iraqi J. Vet. Sci., 26: 63-68.

Sheldon, B.W. and J. Brake, 1991. Hydrogen peroxide as an alternative hatching egg disinfectant. Poultry Sci., 70: 1092-1098. DOI: $10.3382 /$ ps.0701092

Sidhu, M.S., H. Sorum and A. Holck, 2002. Resistance to quaternary ammonium compound in food related bacteria. Microbiol. Drug Resistance, 8: 393-399.

Smith, A., S.P. Rose, R.G. Wells and V. Pirgozliev, 2000. The effect of changing the excreta moisture of caged laying hens on the excreta and the microbial contamination of their egg shells. Br. Poult. Sci., 41: 168-173. DOI: $10.1080 / 713654903$

SPSS 20, 1989-2014. Statistical package for social science. Copy right SPSS Inc.

Stępień-Pyśniak, D., 2010. Occurrence of gram-negative bacteria in hens' eggs depending on their source and storage conditions. Pol. J. Vet. Sci., 13: 507-513. PMID: 21033566

Stępień-Pyśniak, D., A.R. Marek and J. Rzedzicki, 2009. Occurrence of bacteria of the genus Staphylococcus in table eggs descended from different sources. Pol. J. Vet. Sci., 12: 481-484. PMID: 20169921

Suba, S., D. Narahari and T.G. Prabhakar, 2005. Microbial quality and safety of table eggs marketed in commercial channels. Proceedings of the 11th European Symposium on the Quality of Eggs and Egg Products Doorwerth, (EPD' 05), The Netherlands, pp: 23-26.

SVA, 2014. Salmonella in poultry.

Theron, H., P.V. Enter and J.F.R. Lues, 2003. Bacterial growth on chicken eggs in various storage environments. Food Res. Int., 36: 969-975. DOI: $10.1016 / \mathrm{S} 0963-9969(03) 00117-0$ 
Turblin, V., 2012. Good quality chicks from disinfected eggs. CEVA Animal Health, France.

USDA/FSIS, 1998. Microbiology Laboratory Guidebook. 3rd Edn., USDA. Food Safety and Inspection Services. Washington, D.C. USA., ISBN-10: 0160496020.
Wells, J.B., C.D. Coufal, H.M. Parker, A.S. Kiess and K.M. Young et al., 2011. Hatchablility of broiler breeder eggs sanitized with a combination of ultraviolet light and hydrogen peroxide. Int. J. Poultry Sci., 10: 320-324. 